\title{
Novel Tranylcypromine/Hydroxylcinnamic Acid Hybrids as Lysine- Specific Demethylase 1 Inhibitors with Potent Antitumor Activity
}

\author{
Yan Han, ${ }^{*, a}$ Chunlei Wu, ${ }^{a}$ Haifeng $\mathrm{Lv}^{b}{ }^{b} \mathrm{Na} \mathrm{Liu},{ }^{c}$ and Huaying Deng ${ }^{a}$ \\ ${ }^{a}$ Department of Orthopedics, The First Affiliated Hospital, Wenzhou Medical University; Wenzhou 325035, Zhejiang, \\ P.R. China: ${ }^{b}$ School of Pharmacy, Wenzhou Medical University; Wenzhou 325035, Zhejiang, P. R. China: and \\ ${ }^{c}$ Department of Traditional Medical Traumatology Orthopedics, Xi'an Honghui Hospital; Xi'an 710054, Shanxi, P. R. \\ China.
}

Received June 9, 2015; accepted August 12, 2015

Novel tranylcypromine/hydroxylcinnamic acid hybrids 15a, b, and 19a-l were designed and synthesized by connecting tranylcypromine with hydroxylcinnamic acid, and their biological activities were evaluated. The in vitro assay of their inhibitory activities against lysine-specific demethylase 1 (LSD1) showed that most of the target compounds displayed high potency with $\mathrm{IC}_{50}$ values ranging from submicromolar to single-digit micromolar levels. In particular, compound 191 had robust, selective LSD1 inhibitory activity, which was obviously higher than the inhibitory activity against homologues monoamine oxidase-A (MAO-A) and MAO-B, respectively. Furthermore, the most potent compound 191 selectively inhibited cancer cell but not nontumor colon cell proliferation in vitro. In addition, compound 191 also dose-dependently increased the expression of H3K4me2 at the cellular level. Our findings suggest that tranylcypromine/hydroxylcinnamic acid hybrids as LSD1 inhibitors may hold great promise as therapeutic agents for the treatment of human cancers.

Key words synthesis; lysine-specific demethylase; inhibitory activity; tranylcypromine; hydroxylcinnamic acid; antitumor agent

Epigenetic disregulation often leads to the aberrant gene expression programs characteristic of cancer., ${ }^{1,2}$ Transcriptional regulation through chromatin modification is reversible and dynamic such that enzymes implicated in the disregulation of chromatin represent a new class of protein targets for drug development. Lysine-specific demethylase 1 (LSD1) is an epigenetic enzyme that belongs to the amine oxidase protein superfamily, which oxidatively cleaves methyl groups of histone $\mathrm{H} 3$ at lysine 4 (H3K4mel and $\mathrm{H} 3 \mathrm{~K} 4 \mathrm{me} 2)$ and lysine 9 (H3K9mel and H3K9me2) through flavin adenine dinucleotide (FAD)-dependent enzymatic oxidation, and catalyzes methylated lysine substrates to generate hydrogen peroxide and formaldehyde as byproducts ${ }^{3-5)}$ (Fig. 1).

LSD1 is also able to demethylate non-histone substrates, such as the tumor suppressor p53 and the cell cycle and apoptosis regulator E2F1. ${ }^{6,7)}$ Furthermore, LSD1 is often overexpressed in various cancer cells and tissues: neuroblastoma, hepatocarcinomas, colon cancer, breast cancer, gastric cancer, and bladder cancer cells. ${ }^{8-12)}$ LSD1 inhibition decreased expression of target genes in these cancers. Therefore, LSD1 has been considered an important and attractive target for the treatment of cancer. ${ }^{13,14)}$ LSD1 inhibitors are of interest not only as tools to elucidate the biological functions of the enzyme, but also as promising therapeutic agents.

To date, a number of prior LSD1 inhibitors have been reported including monoamine oxidase (MAO) inhibitors such as tranylcypromine (1, PCPA, Fig. 2), pargyline (2), and derivatives thereof (3-6), polyamines (7), peptides (8), as well as guanidine derivatives (9). ${ }^{4,-20)}$ Among these LSD1 inhibitors, PCPA is a classical MAO inhibitor which has been well studied, and biological studies of PCPA have uncovered the important roles of LSD1 in several cancer diseases. ${ }^{21)}$ PCPA inhibits LSD1 involving an oxidative cyclopropylamine ring-opening reaction through a single-electron transfer mechanism. ${ }^{22}$
However, currently PCPA and its derivatives display poor selectivity, low potency, or weak antitumor activity, Therefore, identification of novel potent reversible LSD1 inhibitors is essential to further elucidate LSD1's role in cancer and identify whether or not effective inhibition targeting LSD1 is a viable therapeutic strategy.

As part of our ongoing effort to discover novel anticancer agents, we were inspired by the fact that hydroxylcinnamic acids, such as ferulic acid and $p$-hydroxycinnamic acid, are known as phenolic compounds occurring in natural plant product, and their derivatives displayed selective antiproliferative activity against some types of cancer cells. ${ }^{23-25)}$ On the basis of the aforementioned information, we conjugated tranylcypromine with hydroxylcinnamic acid to afford lead compounds $\mathbf{1 5} \mathbf{a}, \mathbf{b}$, and different amino acid as the linker connected with tranylcypromine and hydroxylcinnamic acid to design novel hybrids 19a-l. We hypothesized that the novel types of tranylcypromine/hydroxylcinnamic acid hybrids will efficaciously develop inhibitory effect of LSD1 and selectively

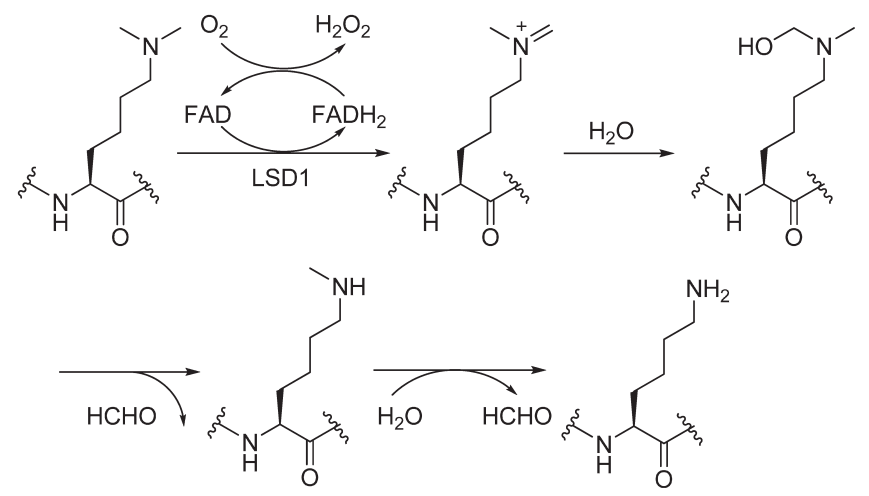

Fig. 1. Reactions Catalyzed by Lysine-Specific Demethylases 
<smiles>CC(C)CCNCCCNC(=S)NCC(c1ccccc1)c1ccccc1</smiles>

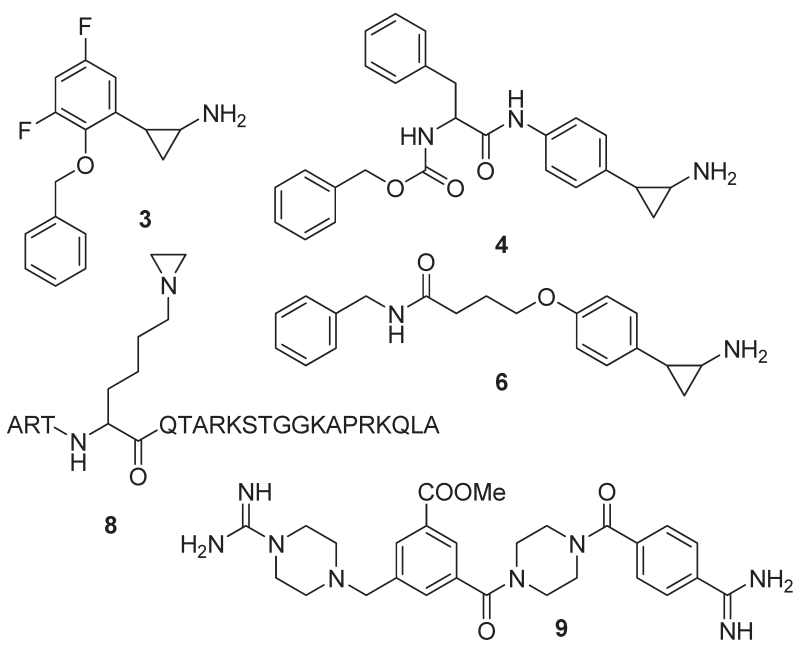

Fig. 2. Representative Structures of Reported LSD1 Inhibitors

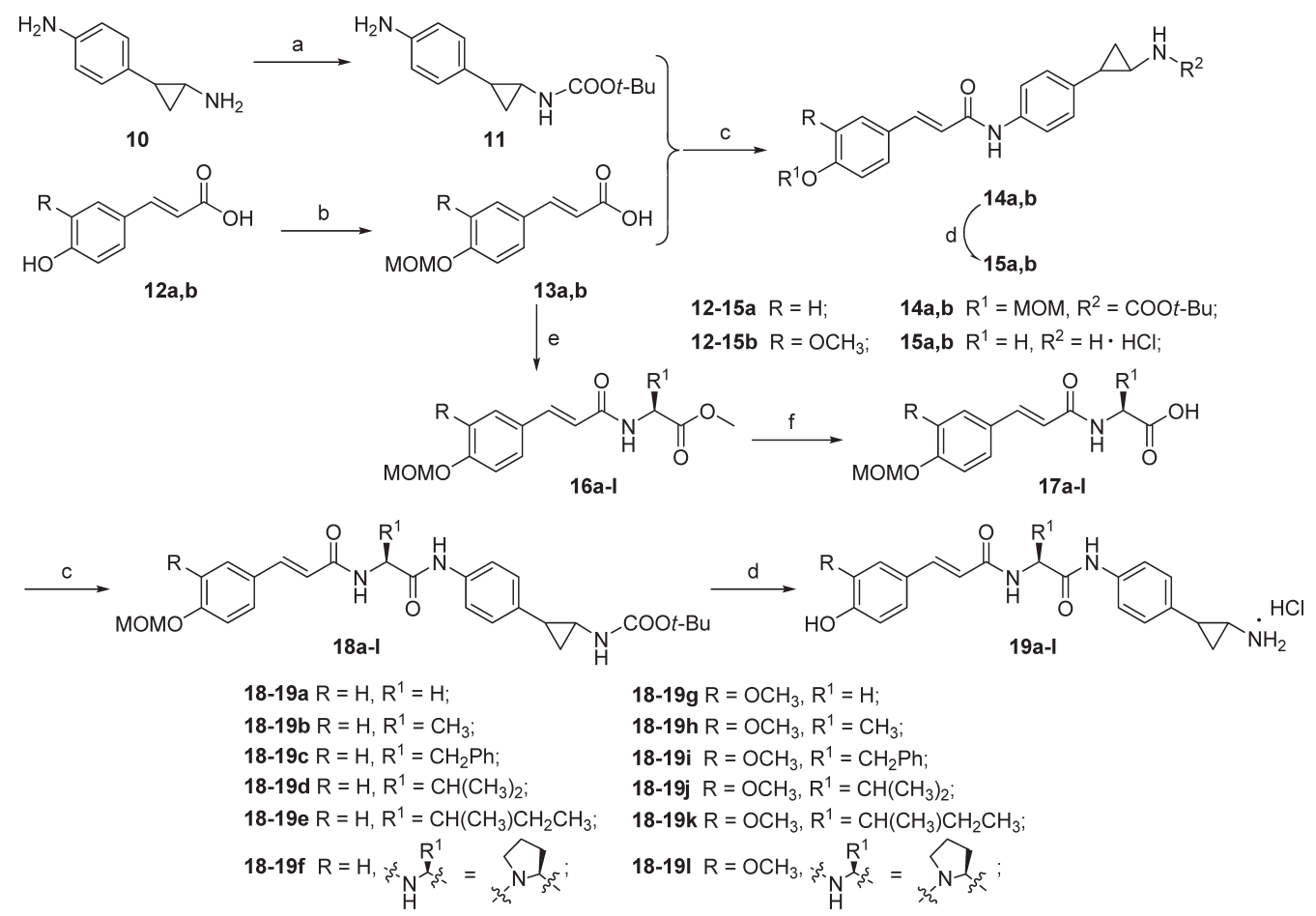

Reaction conditions and reagents: a) Di-t-butyl-dicarbonate, $1 \mathrm{~N} \mathrm{NaOH}, \mathrm{rt}, 10 \mathrm{~h}, 56 \%$; b) MOMCl, $\mathrm{MeCN}, \mathrm{NaH}, \mathrm{rt}, 3 \mathrm{~h}, 67-71 \%$; c) EDCI, DMAP, $\mathrm{CH}_{2} \mathrm{Cl}, \mathrm{rt}_{2}, 5-8 \mathrm{~h}$, 65-77\%; d) Saturated $\mathrm{HCl}$ in dry AcOEt, rt, 6-10h, 88-94\%; e) Different substituted methyl aminoacetate, EDCI, DMAP, $\mathrm{CH}_{2} \mathrm{Cl}_{2}, \mathrm{rt}, 5-10 \mathrm{~h}, 63-72 \%$; f) $1 \mathrm{~N} \mathrm{NaOH}$, $\mathrm{MeOH}, \mathrm{rt}, 1-2 \mathrm{~h}, 86-93 \%$.

Chart 1

inhibit tumor cell proliferation. Therefore, a total of twenty target compounds (15a, b, 19a-l) were designed and synthesized, and their in vitro antitumor effects were investigated. Herein, the synthesis and preliminary biological evaluation of these compounds were reported.

\section{Results and Discussion}

Chemistry The synthetic route to target compounds 15a, b and 19a-l was depicted in Chart 1. Firstly, the alkyl amine of 4-(2-aminocyclopropyl)aniline scaffold $\mathbf{1 0}$ was protected by treatment with di-t-butyl-dicarbonate to generate compound 11, and the phenolic hydroxy of 4-hydroxycinnamic acid 12a or ferulic acid 12b was also protected by etherification with chloromethyl methyl ether (MOM-Cl) to give 13a and $\mathbf{b}$. Then compound 11 was respectively reacted with $\mathbf{1 3 a}$ and $\mathbf{b}$ in the presence of 1-ethyl-(3-(3-dimethylamino)propyl)-carbodiimide hydrochloride (EDCI) and 4-dimethylaminopyridine (DMAP) to gain amidated products $\mathbf{1 4 a}$ and $\mathbf{b}$, which was followed treated with saturated $\mathrm{HCl}$ in dry AcOEt to obtain targeted compounds 15a and b. In addition, compounds 13a and b were also reacted with different substituted methyl aminoacetates to offer intermediates $\mathbf{1 6 a}-\mathbf{l}$, which was further hydrolyzed with $\mathrm{NaOH}$ solution to get compounds $\mathbf{1 7} \mathbf{a}-\mathbf{l}$. Then target compounds $19 \mathbf{a}-\mathbf{l}$ were prepared from intermediates $17 \mathbf{a}-\mathbf{I}$ and $\mathbf{1 1}$ according to the similar synthetic method of $\mathbf{1 5} \mathbf{a}$ and b. The final products $15 \mathbf{a}, \mathbf{b}$, and $19 \mathbf{a}-\mathbf{l}$ were purified by col- 
Table 1. The Structures and LSD1 Inhibitory Acivity $\left(\mathrm{IC}_{50}, \mu \mathrm{M}\right)$ of $\mathbf{1 5 a}, \mathbf{b}$, and $\mathbf{1 9 a}-\mathbf{I}$

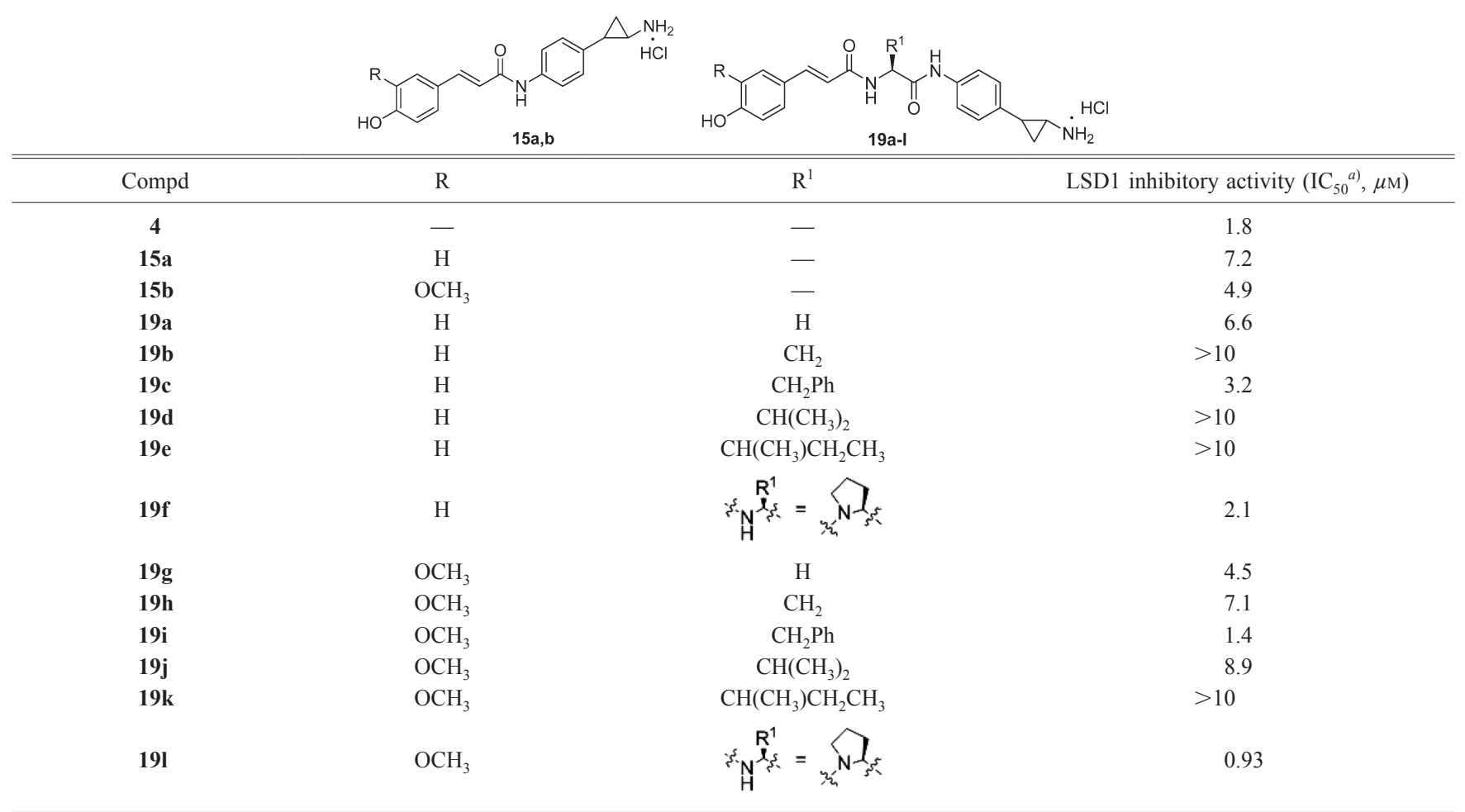

a) Data are expressed as the mean $\mathrm{IC}_{50}$ value from the dose-response curves of at least three independent experiments.

Table 2. LSD1, MAO-A and MAO-B Inhibiting Activity $\left(\mathrm{IC}_{50}\right.$ Values, $\mu \mathrm{M}$ ) of Compounds 19f, $\mathbf{i}$, and $\mathbf{I}$

\begin{tabular}{cccc}
\hline \hline \multirow{2}{*}{ Compd } & \multicolumn{3}{c}{$\mathrm{IC}_{50}{ }^{a}(\mu \mathrm{M})$} \\
\cline { 2 - 4 } & LSD1 & MAO-A & MAO-B \\
\hline $\mathbf{4}$ & 1.8 & 2.3 & $>10$ \\
$\mathbf{1 9 f}$ & 2.1 & 4.1 & $>10$ \\
$\mathbf{1 9 i}$ & 1.4 & 3.7 & $>10$ \\
$\mathbf{1 9 1}$ & 0.93 & 3.6 & $>10$ \\
\hline
\end{tabular}

a) The data are the mean values of $\mathrm{IC}_{50}$ from at least three independent experiments.

umn chromatography, and their structures were characterized by IR, ${ }^{1} \mathrm{H}-\mathrm{NMR}$, MS, and elemental analyses. All compounds were of $>95 \%$ purity determined by HPLC.

Biological Evaluation All the compounds synthesized in this study were examined in vitro for their inhibitory effect on LSD1 activity with a commercialized assay kit. LSD1 inhibitor 4 was used as a positive control. The inhibitory activity results were shown in Table 1. With the exception of compounds $\mathbf{1 9 b}, \mathbf{d}$, e, and $\mathbf{k}$, most of the compounds exhibited moderate to good potency with $\mathrm{IC}_{50}$ values ranging from submicromolar to single-digit micromolar. Among them, compounds 19f, $\mathbf{i}$, and $\mathbf{l}\left(\mathrm{IC}_{50} \mathrm{~s}=0.93-2.1 \mu \mathrm{M}\right)$ were more potent than or comparable to positive control $4\left(\mathrm{IC}_{50}=1.8 \mu \mathrm{M}\right)$. Particularly, compound 19l showed the most potent activity to LSD1, which was nearly 2 times higher than that of 4 .

As LSD1 belongs to the MAO family, the highly potent LSD1 inhibitors 19f, $\mathbf{i}$, and $\mathbf{I}$ were chosen to assay its homologies MAO-A and MAO-B to assess their selectivity profiles using commercially available kits. As shown in Table 2, the inhibitory effects of compounds $\mathbf{1 9 f}, \mathbf{i}$, and $\mathbf{l}$ on MAO-A were
Table 3. The $\mathrm{IC}_{50}$ Values of Active Compounds 19f, $\mathbf{i}$, and $\mathbf{I}$ against Three Human Cancer Cell Lines

\begin{tabular}{cccc}
\hline \hline \multirow{2}{*}{ Compd } & \multicolumn{3}{c}{ Growth inhibition $\left.\left(\mathrm{IC}_{50}{ }^{a}\right), \mu \mathrm{M}\right)$} \\
\cline { 2 - 4 } & HGC-27 cells & HCT116 cells & LP-1 cells \\
\hline $\mathbf{4}$ & 12.8 & 15.1 & 16.3 \\
$\mathbf{1 9 f}$ & 13.5 & 11.8 & 14.5 \\
$\mathbf{1 9 i}$ & 7.9 & 8.8 & 15.2 \\
$\mathbf{1 9 I}$ & 8.1 & 5.3 & 13.4 \\
\hline
\end{tabular}

a) The inhibitory effects of individual compounds on the proliferation of cancer cell lines were determined by the MTT assay. The data are the mean values of $\mathrm{IC}_{50}$ from at least three independent experiments.

nearly 2-4 fold less than those against LSD1, and also less potent than the positive control $\mathbf{4}$ against MAO-A. In addition, all the compounds exhibited no significant inhibitory effects on MAO-B activities.

Next, in order to explore their antitumor activity, active compounds 19f, $\mathbf{i}$, and $\mathbf{I}$ were further evaluated their antiproliferative effects against three human cancer cells HGC-27 (human gastric cancer cells), HCT-116 (human colon carcinoma cells), and LP-1 (human myeloma cells) by 3-(4,5-dimethylthiazol-2-yl)-2,5-diphenyltetrazolium bromide (MTT) assays in vitro, and 4 was used as a positive control. The results (shown in Table 3 ) illustrated the $\mathrm{IC}_{50}$ values of active compounds against each tumor cell line. All the tested compounds showed significant antiproliferative activities, which were similar or stronger anticancer activities than positive control 4 . Among these compounds, compound 19l $\left(\mathrm{IC}_{50} \mathrm{~S}=5.3-13.4 \mu \mathrm{M}\right)$ exhibited higher antiproliferative activities than the other target compounds against three tumor cells, and its $\mathrm{IC}_{50}$ value against HCT-116 cells was nearly 3 -fold less than those of 4 $\left(\mathrm{IC}_{50}=15.1 \mu \mathrm{M}\right)$. 


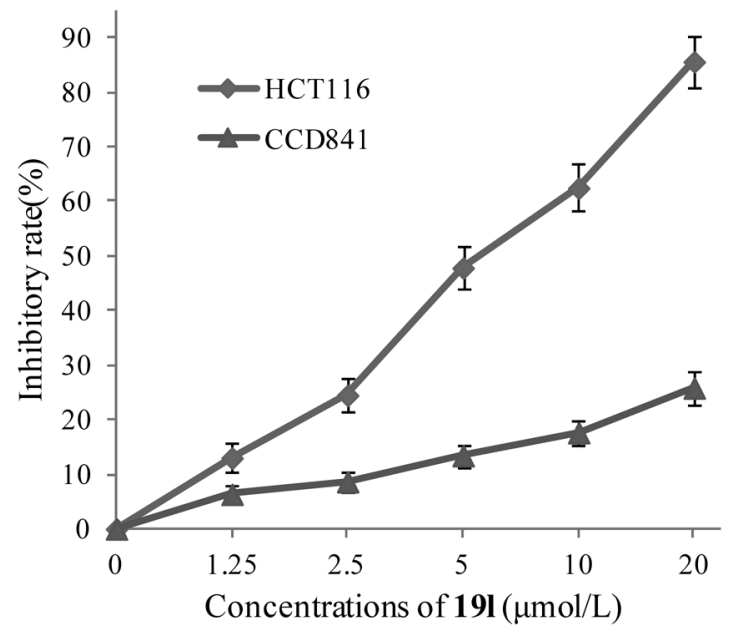

Fig. 3. Inhibitory Effects of $\mathbf{1 9 l}$ on the Proliferation of HCT116 and CCD841 Cells

These cells were incubated with the indicated concentrations of $\mathbf{1 9 l}$ for $48 \mathrm{~h}$. Cell proliferation was assessed using the MTT assay. Data are mean \pm S.D. of the inhibition $(\%)$ from three independent experiments.

Given that these active hybrids showing strong LSD1 and antitumor inhibitory effects, we wonder to know whether those compounds were toxic to the normal cells. So the cytotoxicities of 191 with the highest anticancer activities were further determined for human normal cell CCD841 and human colon carcinoma cells HCT116 by MTT assay. As shown in Fig. 3, treatment with $20 \mu \mathrm{M} 191$ promoted above $85 \%$ of the inhibition in HCT-116 cells, while the same treatment had little significant effect on the survival of CCD-841 cells (less than $25 \%$ of inhibition). Apparently, hybrid 191 had selective cytotoxicity to human cancer cells in vitro.

To get insight into the preliminarily molecular mechanism underlying the LSD1 inhibition on 19l-treated cells, the effects of 191 on the methylation levels of LSD1 substrates H3K4 were analyzed by Western blot analysis in HCT116 cells. The expression of $\mathrm{H} 3 \mathrm{~K} 4$ methylation and histone $\mathrm{H} 3$ were examined using specific antibodies, which were incubated with the vehicle alone (dimethyl sulfoxide (DMSO)), 19l (1.0 or $5.0 \mu \mathrm{M})$, or $4(5.0 \mu \mathrm{M})$. As can be seen in Fig. 4 , after $48 \mathrm{~h}$ treatment with 19l, there was a dose-dependent increase in the H3K4me2 expression, which was slightly stronger than that of 4 at the same concentration of $5.0 \mu \mathrm{M}$. However, there were no significant reproducible changes in $\mathrm{H} 3 \mathrm{~K} 4 \mathrm{me} 1, \mathrm{H} 3 \mathrm{~K} 4 \mathrm{me} 3$, and histone H3. These results validated that compound 19I can specifically inhibit LSD1 activity at the cellular level in HCT116 cells.

Structure-Activity Relationship (SAR) Analysis of SAR revealed that the inhibitory activity of tranylcypromine/ ferulic acid hybrids $\mathbf{1 9 a}-\mathbf{f}$ were more potent against LSD1 than that of tranylcypromine/ $p$-hydroxycinnamic acid hybrids $\mathbf{1 9 g}-\mathbf{l}$, which suggested that the electron-donating substitutions $\left(\mathrm{OCH}_{3}\right)$ on the ferulic acid derivatives may contribute to their inhibitory activities to these molecules. Secondary, hybrids with amino acid linker such as glycine, phenylalanine, or proline, displayed slightly stronger inhibitory effects on LSD1 activity than hybrids $\mathbf{1 5 a}$ and $\mathbf{b}$ without linker. Among these amino acid linkers, different amino acid fragments connected between tranylcypromine and hydroxycinnamic acids were also crucial for their LSD1 inhibitory activities in vitro.

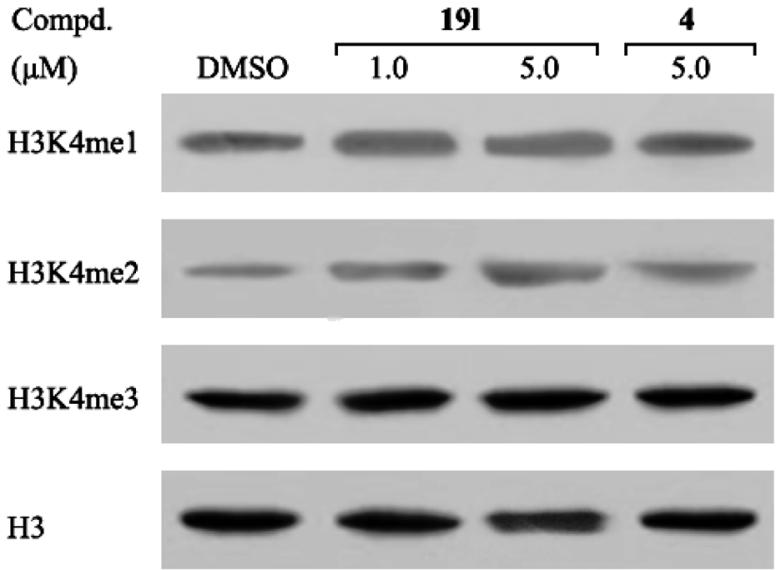

Fig. 4. Immunoblot Analysis of the Expression of $\mathrm{H} 3 \mathrm{~K} 4 \mathrm{me} 1 / \mathrm{me} 2 / \mathrm{me} 3$ and Histone $\mathrm{H} 3$ in Vitro

The total levels of histone H3 were used as loading control. HCT116 cells were incubated with or without 19l, or 4 at the indicated concentrations for $48 \mathrm{~h}$ and the levels of protein expression were detected using $\mathrm{H} 3$ methylation specific antibodies. Data shown are representative images of each protein for three separate experiments.

These hybrid molecules linked with phenylalanine or proline, particularly for proline, exhibited the outstanding inhibitory activities to LSD1 while the hybrids linked with valine or isoleucine showed relatively weak activities.

\section{Conclusion}

In summary, two series of novel hybrid molecules 15a, b, and 19a-l were designed and synthesized by coupling the carboxyl group of hydroxylcinnamic acid with tranylcypromine, and their in vitro biological activities were evaluated. It was discovered that most of target compounds showed promising LSD1 inhibitory activities, particularly for $\mathbf{1 9 f}$, $\mathbf{i}$, and $\mathbf{l}$, which had significant LSD1 inhibitory and antiproliferative activities comparable to or slightly stronger than positive control 4 against human carcinoma cells. Furthermore, compound 19l exhibited significant selectivity for LSD1 over its homologies MAO-A and MAO-B. In addition, compound 19l also could dose-dependently increase the level of H3K4me2 in HCT116 cells. Therefore, our novel work could serve as a foundation for further exploration of novel LSD1 inhibitors for the treatment of cancer.

\section{Experimental}

Melting points were determined on a RDCSY-I capillary apparatus and were uncorrected. The compounds synthesized were purified by column chromatography using silica gel (200-300 mesh) except for recrystallization and TLC using silica gel $60 \mathrm{~F}_{254}$ plates $(250 \mathrm{~mm}$; Qingdao Ocean Chemical Company, China). Infrared (IR) spectra ( $\mathrm{KBr})$ were recorded on a Nicolet Impact 410 instrument $(\mathrm{KBr}$ pellet). ${ }^{1} \mathrm{H}-\mathrm{NMR}$ spectra were recorded with a Bruker Avance $300 \mathrm{MHz}$ spectrometer at $300 \mathrm{~K}$, using tetramethylsilane (TMS) as an internal standard. MS spectra were recorded on a Mariner Mass Spectrum (electrospray ionization (ESI)). Element analysis was performed on an Eager 300 instrument. 4-(2-Aminocyclopropyl)aniline $\mathbf{1 0}$ and compounds $\mathbf{1 2 a}$ and $\mathbf{b}$ were commercially available. All solvents were reagent grade and, when necessary, were purified and dried by standards methods. Solutions after reactions and extractions were con- 
centrated using a rotary evaporator operating at a reduced pressure of $c a$. 20 Torr. Organic solutions were dried over anhydrous sodium sulfate.

tert-Butyl (2-(4-Aminophenyl)cyclopropyl)carbamate (11) To a solution of $\mathbf{1 0}(3.0 \mathrm{~g}, 20 \mathrm{mmol})$ and $1 \mathrm{~m} \mathrm{NaOH}(15 \mathrm{~mL})$ in acetone $(30 \mathrm{~mL})$ at $0^{\circ} \mathrm{C}$ was added $\mathrm{Boc}_{2} \mathrm{O}(4.4 \mathrm{~g}, 20 \mathrm{mmol})$ by slow dropwise. The solution was allowed to warm to room temperature and stirred for $10 \mathrm{~h}$, and then extracted with AcOEt $(30 \times 3 \mathrm{~mL})$. The organic extracts were combined, dried with anhydrous sodium sulfate, filtered, and concentrated to afford $2.8 \mathrm{~g}$ of 11 in $56 \%$ yield. MS (ESI) $m / z=249[\mathrm{M}+\mathrm{H}]^{+}$.

(E)-3-(4-(Methoxymethoxy)phenyl)acrylic Acid (13a) 4-Hydroxycinnamic acid 12a (1.64 g, 10 mmol) was dissolved in acetonitrile $(20 \mathrm{~mL})$, and then $\mathrm{NaH}(0.36 \mathrm{~g}, 15 \mathrm{mmol})$ was added at $0^{\circ} \mathrm{C}$. The mixture was stirred for $10 \mathrm{~min}$ and then added $\mathrm{MOMCl}(0.96 \mathrm{~g}, 12 \mathrm{mmol})$ in acetonitrile $(5 \mathrm{~mL})$ and stirred for another $3 \mathrm{~h}$. After the reaction was completed, the solvent was removed under reduced pressure. The crude residue was dissolved in water and washed with ether $(10 \times 3 \mathrm{~mL})$. The water layer was acidified with $1 \mathrm{M} \mathrm{HCl}$ to $\mathrm{pH} 4$, and the precipitation was collected by filtration to give 13a, yeild $71 \%$. MS (ESI) $m / z=209[\mathrm{M}+\mathrm{H}]^{+}$.

(E)-3-(3-Methoxy-4-(methoxymethoxy)phenyl)acrylic Acid (13b) The title compound was obtained from ferulic acid 12b and $\mathrm{MOMCl}$ according to the synthetic procedure of 13a in yield $67 \%$. MS (ESI) $m / z=239[\mathrm{M}+\mathrm{H}]^{+}$.

(E)-N-(4-(2-Aminocyclopropyl)phenyl)-3-(4-hydroxyphenyl)acrylamide Hydrochloride (15a) A mixture of compounds $11(0.25 \mathrm{~g}, 1.01 \mathrm{mmol})$ and 13a $(0.2 \mathrm{~g}, 0.96 \mathrm{mmol})$, EDCI $(0.27 \mathrm{~g}, 1.44 \mathrm{mmol})$ and catalytic amounts of DMAP in $\mathrm{CH}_{2} \mathrm{Cl}_{2}(10 \mathrm{~mL})$ was stirred at room temperature overnight. Then $20 \mathrm{~mL}$ of $\mathrm{CH}_{2} \mathrm{Cl}_{2}$ was added and the mixture was washed with water $(30 \mathrm{~mL} \times 3)$ and brine. The organic phase was dried over anhydrous sodium sulfate, filtered and evaporated to afford the crude product, which was then purified by column chromatography to give compound 14a. Then compound 14a was dissolved in $15 \mathrm{~mL}$ of saturated $\mathrm{HCl}$ in dry AcOEt and the reaction was stirred at room temperature for $8 \mathrm{~h}$. The solvent was evaporated in vacuo to give compound 15a, yield $61 \%$. Analytical data for 15a: IR $\left(\mathrm{KBr}, \mathrm{cm}^{-1}\right)$ : 3465, 3225, 2926, $1712,1629,1585,1241,1192 ;{ }^{1} \mathrm{H}-\mathrm{NMR}$ (DMSO- $d_{6}, 300 \mathrm{MHz}$, $\delta$ ppm) 10.29 (brs, 1H, PhN $\underline{H C O}$ ), 8.34 (brs, $3 \mathrm{H}, \mathrm{NH}_{3} \mathrm{Cl}$ ), 7.70 (d, $J=6.9 \mathrm{~Hz}, 2 \mathrm{H}, \mathrm{ArH}), 7 . \overline{59}(\mathrm{~d}, 2 \mathrm{H}, J=6.9 \mathrm{~Hz}, \overline{\mathrm{Ar}}-\mathrm{H}), 7.40$ (d, $1 \mathrm{H}, J=16.2 \mathrm{~Hz}, \mathrm{ArCH}=), 7.13-7.18(\mathrm{~m}, 4 \mathrm{H}, \mathrm{Ar}-\mathrm{H}), 6.55(\mathrm{~d}$, $1 \mathrm{H}, J=16.2 \mathrm{~Hz}, \mathrm{C} \underline{\mathrm{H}}=\mathrm{CH}-\mathrm{Ar}), 2.78(\mathrm{~m}, 1 \mathrm{H}, \mathrm{C} \underline{\mathrm{HN}}), 2.27$ (m, $1 \mathrm{H}, \mathrm{PhCH}), 1.35$ (m, 1H, $\mathrm{CH} \underline{\mathrm{H}}$ cyclopropane), $1.23(\mathrm{~m}, 1 \mathrm{H}$, CHH cyclopropane); MS (ESI) $m / z=330[\mathrm{M}]^{+}$. Anal. Calcd for $\mathrm{C}_{18} \mathrm{H}_{19} \mathrm{ClN}_{2} \mathrm{O}_{2}$ : C, 65.35; H, 5.79; N, 8.47. Found: C, 65.28; H, $5.92 ; \mathrm{N}, 8.41$.

(E)-N-(4-(2-Aminocyclopropyl)phenyl)-3-(4-hydroxy3-methoxyphenyl)acrylamide Hydrochloride (15b) The title compound was obtained from compounds $\mathbf{1 1}$ and $\mathbf{1 3 b}$ according to the synthetic procedure of 15a in yield 57\%. Analytical data for 15b: IR ( $\left.\mathrm{KBr}, \mathrm{cm}^{-1}\right)$ : 3448, 3220, 2933, 1710, 1618, 1570, 1245, 1183; ${ }^{1} \mathrm{H}-\mathrm{NMR}$ (DMSO- $d_{6}, 300 \mathrm{MHz}, \delta \mathrm{ppm}$ ) 10.21 (brs, $1 \mathrm{H}, \mathrm{PhNHCO}$ ), 8.31 (br s, $3 \mathrm{H}, \mathrm{NH}_{3} \mathrm{Cl}$ ), 7.68 (d, $2 \mathrm{H}$, $J=6.9 \mathrm{~Hz}, \mathrm{ArH}), 7 . \overline{4}(\mathrm{~d}, 1 \mathrm{H}, J=16.2 \mathrm{~Hz}, \overline{\mathrm{ArCH}}=), 7.13-7.22$ (m, 5H, Ar-H), $6.61(\mathrm{~d}, 1 \mathrm{H}, J=16.2 \mathrm{~Hz}, \mathrm{CH}=\mathrm{C} \overline{\mathrm{H}}-\mathrm{Ar}), 2.75$ (m, $1 \mathrm{H}, \mathrm{CHN}), 2.28$ (m, 1H, PhCH $), 1.33$ (m, 1 $1 \mathrm{H}, \mathrm{CH} \underline{\mathrm{H}}$ cyclopropane), 1.19 (m, 1H, CHH cyclopropane); MS (ESI) $\mathrm{m} / \mathrm{z}=360$ $[\mathrm{M}]^{+}$. Anal. Calcd for $\overline{\mathrm{C}}_{19} \mathrm{H}_{21} \mathrm{ClN}_{2} \mathrm{O}_{3} \cdot \mathrm{H}_{2} \mathrm{O}: \mathrm{C}, 60.24 ; \mathrm{H}, 6.12$;
N, 7.39. Found: C, 60.08; H, 6.27; N, 7.31.

(E)-2-(3-(4-(Methoxymethoxy)phenyl)acrylamido)acetic Acid (17a) To a solution of 13a $(0.2 \mathrm{~g}, 0.96 \mathrm{mmol})$ in dry $\mathrm{CH}_{2} \mathrm{Cl}_{2}(10 \mathrm{~mL})$, methyl 2-aminoacetate $(0.10 \mathrm{~g}, 1.12 \mathrm{mmol})$, EDCI $(0.27 \mathrm{~g}, 1.44 \mathrm{mmol})$ and catalytic amounts of DMAP was added and the mixture was stirred at room temperature overnight. Then $20 \mathrm{~mL}$ of $\mathrm{CH}_{2} \mathrm{Cl}_{2}$ was added and the mixture was washed with water $(30 \mathrm{~mL} \times 3)$ and brine. The organic phase was dried over anhydrous sodium sulfate, filtered and evaporated in vacuo, and the crude product was purified by column chromatography to give 16a, which was then dissolved in $5 \mathrm{~mL}$ methanol containing $1.5 \mathrm{~mL} 2 \mathrm{M} \mathrm{NaOH}$. The reaction was stirred and refluxed for $3 \mathrm{~h}$, and then cooled. The solvent was evaporated in vacuo, the residue was neutralized to $\mathrm{pH}=5$ with $1 \mathrm{M} \mathrm{HCl}$. The precipitate was filtered, washed with water, and dried in vacuum to afford $17 \mathbf{a}$ in yield $69 \%$. MS (ESI) $m / z=266[\mathrm{M}+\mathrm{H}]^{+}$.

(S,E)-2-(3-(4-(Methoxymethoxy)phenyl)acrylamido)propanoic Acid (17b) The title compound was obtained from 13a and $(S)$-methyl 2-aminopropanoate according to the synthetic procedure of $\mathbf{1 7 a}$ in yield $67 \%$. MS (ESI) $\mathrm{m} / \mathrm{z}=280$ $[\mathrm{M}+\mathrm{H}]^{+}$.

$(S, E)-2-(3-(4-(M e t h o x y m e t h o x y) p h e n y l) a c r y l a m i d o)-$ 3-phenylpropanoic Acid (17c) The title compound was obtained from 13a and $(S)$-methyl 2-amino-3-phenylpropanoate according to the synthetic procedure of $17 \mathrm{a}$ in yield $66 \%$. MS (ESI) $m / z=356[\mathrm{M}+\mathrm{H}]^{+}$.

$(S, E)-2-(3-(4-(M e t h o x y m e t h o x y) p h e n y l) a c r y l a m i d o)-$ 3-methylbutanoic Acid (17d) The title compound was obtained from 13a and $(S)$-methyl 2-amino-3-methylbutanoate according to the synthetic procedure of $17 \mathbf{a}$ in yield $66 \%$. MS (ESI) $m / z=368[\mathrm{M}+\mathrm{H}]^{+}$.

(S,E)-2-(3-(4-(Methoxymethoxy)phenyl)acrylamido)3-methylpentanoic Acid (17e) The title compound was obtained from 13a and (2S,3R)-methyl 2-amino-3-methylpentanoate according to the synthetic procedure of $17 \mathbf{a}$ in yield $63 \%$. MS (ESI) $m / z=322[\mathrm{M}+\mathrm{H}]^{+}$.

(S,E)-1-(3-(4-(Methoxymethoxy)phenyl)acryloyl)pyrrolidine-2-carboxylic Acid (17f) The title compound was obtained from 13a and $(S)$-methyl pyrrolidine-2-carboxylate according to the synthetic procedure of $\mathbf{1 7 a}$ in yield $61 \%$. MS (ESI) $m / z=306[\mathrm{M}+\mathrm{H}]^{+}$.

(E)-2-(3-(3-Methoxy-4-(methoxymethoxy)phenyl)acrylamido)acetic Acid (17g) The title compound was obtained from 13b and methyl 2-aminoacetate according to the synthetic procedure of $17 \mathbf{a}$ in yield $65 \%$. MS (ESI) $m / z=296[\mathrm{M}+\mathrm{H}]^{+}$.

$(S, E)-2-(3-(3-M e t h o x y-4-(m e t h o x y m e t h o x y) p h e n y l) a c r y l-$ amido)propanoic Acid (17h) The title compound was obtained from 13b and $(S)$-methyl 2-aminopropanoate according to the synthetic procedure of $17 \mathbf{a}$ in yield $67 \%$. MS (ESI) $m / z=310[\mathrm{M}+\mathrm{H}]^{+}$.

(S,E)-2-(3-(3-Methoxy-4-(methoxy methoxy)phenyl)acrylamido)-3-phenylpropanoic Acid (17i) The title compound was obtained from $\mathbf{1 3 b}$ and $(S)$-methyl 2-amino3-phenylpropanoate according to the synthetic procedure of 17 a in yield $63 \%$. MS (ESI) $m / z=386[\mathrm{M}+\mathrm{H}]^{+}$.

$(S, E)$-2-(3-(3-Methoxy-4-(methoxymethoxy)phenyl)acrylamido)-3-methylbutanoic Acid (17j) The title compound was obtained from $\mathbf{1 3 b}$ and $(S)$-methyl 2-amino3-methylbutanoate according to the synthetic procedure of 17a in yield $60 \%$. MS (ESI) $m / z=338[\mathrm{M}+\mathrm{H}]^{+}$. 
$(S, E)-2-(3-(3-M e t h o x y-4-(m e t h o x y m e t h o x y) p h e n y l)-$ acrylamido)-3-methylpentanoic Acid (17k) The title compound was obtained from $\mathbf{1 3 b}$ and $(2 S, 3 R)$-methyl 2-amino3-methylpentanoate according to the synthetic procedure of $17 \mathbf{a}$ in yield $62 \%$. MS (ESI) $m / z=352[\mathrm{M}+\mathrm{H}]^{+}$.

(S,E)-1-(3-(3-Methoxy-4-(methoxymethoxy)phenyl)acryloyl)pyrrolidine-2-carboxylic Acid (17l) The title compound was obtained from $\mathbf{1 3 b}$ and $(S)$-methyl pyrrolidine2-carboxylate according to the synthetic procedure of $17 \mathbf{a}$ in yield $57 \%$. MS (ESI) $m / z=336[\mathrm{M}+\mathrm{H}]^{+}$.

(E)-N-(2-((4-(2-Aminocyclopropyl)phenyl)amino)2-oxoethyl)-3-(4-hydroxyphenyl)acrylamide Hydrochloride (19a) The title compound was obtained from compounds $\mathbf{1 1}$ and $17 \mathbf{a}$ according to the synthetic procedure of $\mathbf{1 5} \mathbf{a}$ in yield 59\%. Analytical data for 19a: IR $\left(\mathrm{KBr}, \mathrm{cm}^{-1}\right)$ : 3432, 2941, 1725, 1620, 1577, 1265, 1187; ${ }^{1} \mathrm{H}-\mathrm{NMR}$ (DMSO- $d_{6}, 300 \mathrm{MHz}$, $\delta$ ppm) 10.31 (brs, 1H, PhNHCO), 10.16 (brs, 1H, NHCO), 8.33 (brs, 3H, $\mathrm{NH}_{3} \mathrm{Cl}$ ), 7.71 (d, $\left.J=6.9 \mathrm{~Hz}, 2 \mathrm{H}, \operatorname{ArH}\right), 7.59$ (d, $2 \mathrm{H}, J=6.9 \mathrm{~Hz}, \mathrm{Ar}-\mathrm{H}), 7.41(\mathrm{~d}, 1 \mathrm{H}, J=16.2 \mathrm{~Hz}, \mathrm{ArCH}=)$, 7.15-7.19 (m, 4H, Ar-H), $6.57(\mathrm{~d}, 1 \mathrm{H}, J=16.2 \mathrm{~Hz}, \mathrm{CH}=\mathrm{CH}-$ Ar), $3.73\left(\mathrm{~m}, 2 \mathrm{H}, \mathrm{NCH}_{2}\right), 2.78(\mathrm{~m}, 1 \mathrm{H}, \mathrm{CHN}), 2.29(\mathrm{~m}, 1 \mathrm{H}$,

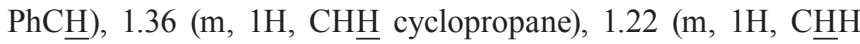
cyclopropane); MS (ESI) $m / z=387\left[\mathrm{M}^{+}\right.$. Anal. Calcd for $\mathrm{C}_{20} \mathrm{H}_{22} \mathrm{ClN}_{3} \mathrm{O}_{3}: \mathrm{C}, 61.93 ; \mathrm{H}, 5.72 ; \mathrm{N}, 10.83$. Found: $\mathrm{C}, 61.76 ; \mathrm{H}$, $5.85 ; \mathrm{N}, 10.69$.

(E)-N-((2S)-1-((4-(2-Aminocyclopropyl)phenyl)amino)1-oxopropan-2-yl)-3-(4-hydroxyphenyl)acrylamide Hydrochloride (19b) The title compound was obtained from compounds 11 and $\mathbf{1 7 b}$ according to the synthetic procedure of $15 \mathbf{a}$ in yield $55 \%$. Analytical data for $19 \mathbf{b}$ : IR $\left(\mathrm{KBr}, \mathrm{cm}^{-1}\right)$ : 3440, 3236, 2942, 1718, 1620, 1573, 1258, 1176; ${ }^{1} \mathrm{H}-\mathrm{NMR}$ (DMSO- $d_{6}, 300 \mathrm{MHz}, \delta$ ppm) 10.27 (brs, 1H, PhNHCO), 10.11 (brs, $1 \mathrm{H}, \mathrm{PhNHCO}$ ), 8.36 (brs, $3 \mathrm{H}, \mathrm{NH}_{3} \mathrm{Cl}$ ), $7 . \overline{71}$ (d, $J=6.9 \mathrm{~Hz}, 2 \mathrm{H}, \mathrm{ArH}), 7.61(\mathrm{~d}, 2 \mathrm{H}, J=6.9 \mathrm{~Hz}, \overline{\mathrm{Ar}}-\mathrm{H}), 7.41$ (d, $1 \mathrm{H}, J=16.2 \mathrm{~Hz}, \mathrm{ArCH}=), 7.15-7.19(\mathrm{~m}, 4 \mathrm{H}, \mathrm{Ar}-\mathrm{H}), 6.56(\mathrm{~d}, 1 \mathrm{H}$, $J=16.2 \mathrm{~Hz}, \mathrm{CH}=\mathrm{CH}-\mathrm{Ar}), 4.75(\mathrm{~m}, 1 \mathrm{H}, \mathrm{NCHCO}), 2.80(\mathrm{~m}, 1 \mathrm{H}$,

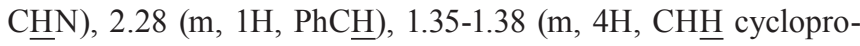
pane, $\mathrm{NCHCH}_{3}$ ), 1.23 (m, 1H, C $m / z=401[\mathrm{M}]^{+}$. Anal. Calcd for $\mathrm{C}_{21} \mathrm{H}_{24} \mathrm{ClN}_{3} \mathrm{O}_{3}: \mathrm{C}, 62.76 ; \mathrm{H}$, 6.02; N, 10.46. Found: C, 62.58; H, 6.23; N, 10.35.

(E)-N-((2S)-1-((4-(2-Aminocyclopropyl)phenyl)amino)1-oxo-3-phenylpropan-2-yl)-3-(4-hydroxyphenyl)acrylamide Hydrochloride (19c) The title compound was obtained from compounds $\mathbf{1 1}$ and $\mathbf{1 7} \mathrm{c}$ according to the synthetic procedure of $\mathbf{1 5} \mathbf{a}$ in yield $51 \%$. Analytical data for 19c: IR $\left(\mathrm{KBr}, \mathrm{cm}^{-1}\right)$ : 3455, 3228, 1726, 1622, 1573, 1246, 1182; ${ }^{1} \mathrm{H}-\mathrm{NMR}$ (DMSO- $d_{6}, 300 \mathrm{MHz}, \delta$ ppm) 10.13 (brs, $1 \mathrm{H}, \mathrm{NHCO}$ ), 8.36 (brs, 3H, $\left.\mathrm{NH}_{3} \mathrm{Cl}\right), 7.69$ (d, $2 \mathrm{H}, J=6.9 \mathrm{~Hz}$, $\operatorname{ArH}), \overline{7} .58(\mathrm{~d}, 2 \mathrm{H}, J=6.9 \mathrm{~Hz}, \overline{\operatorname{Ar}}-\mathrm{H}), 7.41(\mathrm{~d}, 1 \mathrm{H}, J=16.2 \mathrm{~Hz}$, $\mathrm{ArCH}=), 7.22-7.28$ (m, 3H, Ar-H), 7.15-7.18 (m, 6H, Ar-H), $6.60(\mathrm{~d}, 1 \mathrm{H}, J=16.2 \mathrm{~Hz}, \mathrm{CH}=\mathrm{CH}-\mathrm{Ar}), 5.11(\mathrm{~m}, 1 \mathrm{H}, \mathrm{NCHCO})$, 3.09 (d, 2H,J=6.0 Hz, PhC $\left.\underline{\mathrm{C}}_{2}\right), 2.77(\mathrm{~m}, 1 \mathrm{H}, \mathrm{C} \underline{\mathrm{HN}}), 2.29$ (m, $1 \mathrm{H}, \mathrm{PhCH}), 1.36(\mathrm{~m}, 1 \mathrm{H}, \overline{\mathrm{CH}} \underline{\mathrm{H}}$ cyclopropane), $1.21(\mathrm{~m}, 1 \mathrm{H}$, CHH cyclopropane); MS (ESI) $m / z=477\left[\mathrm{M}^{+}\right.$. Anal. Calcd for $\mathrm{C}_{27} \mathrm{H}_{28} \mathrm{ClN}_{3} \mathrm{O}_{3} \cdot 3 \mathrm{H}_{2} \mathrm{O}: \mathrm{C}, 60.95 ; \mathrm{H}, 6.44 ; \mathrm{N}, 7.90$. Found: $\mathrm{C}$, $60.78 ; \mathrm{H}, 6.58 ; \mathrm{N}, 7.79$.

(2S)-N-(4-(2-Aminocyclopropyl)phenyl)-2-((E)-3-(4-hydroxyphenyl)acrylamido)-3-methylbutanamide Hydrochloride (19d) The title compound was obtained from compounds $\mathbf{1 1}$ and $\mathbf{1 7 d}$ according to the synthetic procedure of 15a in yield $53 \%$. Analytical data for 19d: IR $\left(\mathrm{KBr}, \mathrm{cm}^{-1}\right)$ :
3446, 3234, 2938, 1724, 1617, 1575, 1252, 1181; ${ }^{1} \mathrm{H}-\mathrm{NMR}$ (DMSO- $d_{6}, 300 \mathrm{MHz}, \delta$ ppm) 10.15 (brs, 1H, NHCO), 8.19 (brs, $\left.3 \mathrm{H}, \mathrm{NH}_{3} \mathrm{Cl}\right), 7.66(\mathrm{~d}, 2 \mathrm{H}, J=6.9 \mathrm{~Hz}, \mathrm{ArH}), 7.57(\mathrm{~m}, 2 \mathrm{H}$, Ar-H), 7.39 (d, 1H, J=16.2 Hz, ArCH=), 7.13-7.17 (m, 4H, Ar-H), $6.58(\mathrm{~d}, 1 \mathrm{H}, J=16.2 \mathrm{~Hz}, \mathrm{CH}=\mathrm{CH}-\mathrm{Ar}), 4.65(\mathrm{~m}, 1 \mathrm{H}$, NCHCO), $2.73(\mathrm{~m}, 1 \mathrm{H}, \mathrm{CHN}), 2.6 \overline{6}(\mathrm{~m}, 1 \mathrm{H}, \mathrm{NCHCH}), 2.27$ (m, 1H, PhCH $), 1.35(\mathrm{~m}, 1 \overline{\mathrm{H}}, \mathrm{CH} \underline{\mathrm{H}}$ cyclopropane), $1.17(\mathrm{~m}, 1 \mathrm{H}$, C $\underline{H}$ H cyclopropane), 0.93 (d, $\left.6 \mathrm{H}, \bar{J}=7.5 \mathrm{~Hz}, 2 \times \mathrm{CH}_{3}\right)$; MS (ESI) $m / z=429[\mathrm{M}]^{+}$. Anal. Calcd for $\mathrm{C}_{23} \mathrm{H}_{28} \mathrm{ClN}_{3} \mathrm{O}_{3}: \mathrm{C}, 64.25 ; \mathrm{H}$, 6.56; N, 9.77. Found: C, 64.06; H, 6.68; N, 9.62.

(2S)-N-(4-(2-A minocyclopropyl)phenyl)-2-((E)-3-(4hydroxyphenyl)acrylamido)-3-methylpentanamide Hydrochloride (19e) The title compound was obtained from compounds 11 and $\mathbf{1 7 e}$ according to the synthetic procedure of $\mathbf{1 5 a}$ in yield 53\%. Analytical data for 19e: IR $\left(\mathrm{KBr}, \mathrm{cm}^{-1}\right)$ : 3471 , 3242, 2940, 1728, 1621, 1569, 1250, 1186; ' $\mathrm{H}-\mathrm{NMR}$ (DMSO$\left.d_{6}, 300 \mathrm{MHz}, \delta \mathrm{ppm}\right) 10.25$ (brs, $\left.1 \mathrm{H}, \mathrm{NHCO}\right), 8.28$ (brs, 3H, $\left.\mathrm{NH}_{3} \mathrm{Cl}\right), 7.70(\mathrm{~d}, J=6.9 \mathrm{~Hz}, 2 \mathrm{H}, \mathrm{ArH}), 7.5 \overline{9}$ (m, 2H, Ar-H), 7.40 (d, $1 \mathrm{H}, J=16.2 \mathrm{~Hz}, \mathrm{ArCH}=), 7.13-7.18(\mathrm{~m}, 4 \mathrm{H}, \mathrm{Ar}-\mathrm{H}), 6.56(\mathrm{~d}$, $1 \mathrm{H}, J=16.2 \mathrm{~Hz}, \mathrm{CH}=\mathrm{CH}-\mathrm{Ar}), 4.55(\mathrm{~m}, 1 \mathrm{H}, \mathrm{NCHCO}), 2.76(\mathrm{~m}$, $1 \mathrm{H}, \mathrm{CHN}), 2.28$ (m, 1H, PhCH), 2.17 (m, 1H, NCHCH), 1.36

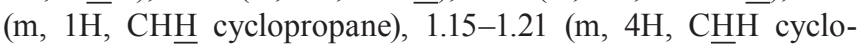
propane, $\left.\mathrm{CH}_{3}\right), 0.92\left(\mathrm{~m}, 3 \mathrm{H}, \mathrm{CH}_{3}\right) ; \mathrm{MS}(\mathrm{ESI}) \mathrm{m} / z=443[\mathrm{M}]^{+}$. Anal. Calcd for $\mathrm{C}_{24} \mathrm{H}_{30} \mathrm{ClN}_{3} \mathrm{O}_{3} \cdot 0.5 \mathrm{H}_{2} \mathrm{O}: \mathrm{C}, 63.64 ; \mathrm{H}, 6.90 ; \mathrm{N}$, 9.28. Found: C, 63.78; H, 7.02; N, 9.36.

(2S)-N-(4-(2-Aminocyclopropyl)phenyl)-1-((E)-3-(4-hydroxyphenyl)acryloyl)pyrrolidine-2-carboxamide Hydrochloride (19f) The title compound was obtained from compounds $\mathbf{1 1}$ and $\mathbf{1 7 f}$ according to the synthetic procedure of $15 \mathbf{a}$ in yield $48 \%$. Analytical data for 19f: IR $\left(\mathrm{KBr}, \mathrm{cm}^{-1}\right)$ : 3457, 3234, 2918, 1719, 1621, 1568, 1255, 1178; ${ }^{1} \mathrm{H}-\mathrm{NMR}$ (DMSO- $d_{6}, 300 \mathrm{MHz}, \delta$ ppm) 10.36 (brs, $1 \mathrm{H}, \mathrm{PhNHCO}$ ), 8.37 (brs, 3H, $\mathrm{NH}_{3} \mathrm{Cl}$ ), 7.72 (d, $\left.J=6.9 \mathrm{~Hz}, 2 \mathrm{H}, \mathrm{ArH}\right), \overline{7.61}$ (d, $2 \mathrm{H}$, $J=6.9 \mathrm{~Hz}, \mathrm{Ar}-\mathrm{H}), 7.42$ (d, $1 \mathrm{H}, J=16.2 \mathrm{~Hz}, \mathrm{ArCH}=), 7.17-7.19$ $(\mathrm{m}, 4 \mathrm{H}, \mathrm{Ar}-\mathrm{H}), 6.56(\mathrm{~d}, 1 \mathrm{H}, J=16.2 \mathrm{~Hz}, \mathrm{CH}=\mathrm{CH}-\mathrm{Ar}), 4.46$ (m, 1H, NCHCO), $3.48\left(\mathrm{~m}, 2 \mathrm{H}, \mathrm{NCH}_{2}\right), 2.81$ (m, 1H, CHN), $2.30(\mathrm{~m}, 1 \mathrm{H}, \mathrm{PhCH}), 2.03\left(\mathrm{~m}, 2 \mathrm{H}, \mathrm{NCHCH}_{2}\right), 1.68(\mathrm{~m}, 2 \mathrm{H}$, $\left.\mathrm{NCH}_{2} \underline{\mathrm{CH}}_{2}\right), 1.38$ (m, 1H, CH프 cyclopropane), $1.24(\mathrm{~m}, 1 \mathrm{H}$, CHH cyclopropane); MS (ESI) $m / z=427[\mathrm{M}]^{+}$. Anal. Calcd for $\mathrm{C}_{23} \mathrm{H}_{26} \mathrm{ClN}_{3} \mathrm{O}_{3}$ : C, 64.55; H, 6.12; N, 9.82. Found: C, 64.46; H, $6.29 ; \mathrm{N}, 9.71$.

(E)-N-(2-((4-(2-A minocyclopropyl)phenyl)amino)2-oxoethyl)-3-(4-hydroxy-3-methoxyphenyl)acrylamide Hydrochloride (19g) The title compound was obtained from compounds $\mathbf{1 1}$ and $\mathbf{1 7 g}$ according to the synthetic procedure of $15 \mathrm{a}$ in yield $56 \%$. Analytical data for $19 \mathrm{~g}$ : IR $\left(\mathrm{KBr}, \mathrm{cm}^{-1}\right)$ : 3477, 3248, 2935, 1726, 1615, 1568, 1250, 1172; ${ }^{1} \mathrm{H}-\mathrm{NMR}$ (DMSO- $\left.d_{6}, 300 \mathrm{MHz}, \delta \mathrm{ppm}\right) 10.35$ (brs, 1H, PhN 10.17 (brs, 1H, NHCO), 8.39 (brs, 3H, $\mathrm{NH}_{3} \mathrm{Cl}$ ), 7.77 (d, $2 \mathrm{H}$, $J=6.9 \mathrm{~Hz}, \mathrm{ArH}), \overline{7.43}(\mathrm{~d}, 1 \mathrm{H}, J=16.2 \mathrm{~Hz}, \overline{\mathrm{ArCH}}=), 7.13-7.22$ (m, 5H, Ar-H), $6.65(\mathrm{~d}, 1 \mathrm{H}, J=16.2 \mathrm{~Hz}, \mathrm{CH}=\mathrm{CH}-\mathrm{Ar}), 3.76(\mathrm{~m}$, $\left.2 \mathrm{H}, \mathrm{NC}_{2}\right), 2.83(\mathrm{~m}, 1 \mathrm{H}, \mathrm{C} \underline{\mathrm{HN}}), 2.32(\mathrm{~m}, \overline{1} \mathrm{H}, \mathrm{PhC} \underline{\mathrm{H}}), 1.38(\mathrm{~m}$, $1 \mathrm{H}, \mathrm{CH} \underline{\mathrm{H}}$ cyclopropane), 1.25 (m, 1H, CHH cyclopropane); MS (ESI) $m / z=417[\mathrm{M}]^{+}$. Anal. Calcd for $\mathrm{C}_{21} \mathrm{H}_{24} \mathrm{ClN}_{3} \mathrm{O}_{4}: \mathrm{C}$, 60.36; H, 5.79; N, 10.06. Found: C, 60.17; H, 5.93; N, 9.92.

(E)-N-((2S)-1-((4-(2-Aminocyclopropyl)phenyl)amino)1-oxopropan-2-yl)-3-(4-hydroxyphenyl)acrylamide Hydrochloride (19h) The title compound was obtained from compounds $\mathbf{1 1}$ and $\mathbf{1 7 h}$ according to the synthetic procedure of $\mathbf{1 5 a}$ in yield $51 \%$. Analytical data for $\mathbf{1 9 h}$ : IR $\left(\mathrm{KBr}, \mathrm{cm}^{-1}\right)$ : 3468, 3232, 1715, 1622, 1565, 1253, 1184; ${ }^{1} \mathrm{H}-\mathrm{NMR}$ (DMSO- 
$\left.d_{6}, 300 \mathrm{MHz}, \delta \mathrm{ppm}\right) 10.14$ (brs, 1H, NHCO), 8.34 (brs, 3H, $\left.\mathrm{NH}_{3} \mathrm{Cl}\right), 7.72(\mathrm{~d}, J=6.9 \mathrm{~Hz}, 2 \mathrm{H}, \mathrm{ArH}), 7 . \overline{60}$ (m, 2H, Ar-H), 7.41 (d, $1 \mathrm{H}, J=16.2 \mathrm{~Hz}, \operatorname{ArCH}=), 7.11-7.18$ (m, 5H, Ar-H), 6.58 (d, $1 \mathrm{H}, J=16.2 \mathrm{~Hz}, \mathrm{CH}=\mathrm{CH}-\mathrm{Ar}), 4.77(\mathrm{~m}, 1 \mathrm{H}, \mathrm{NCHCO}), 2.83(\mathrm{~m}$, 1H, CHN), 2.29 (m, 1H, PhCH), 1.36-1.42 (m, 4H, CHㅡ cyclopropane, $\mathrm{NCHCH}_{3}$ ), 1.23 (m, 1H, $\underline{\mathrm{CHH}}$ cyclopropane); $\mathrm{MS}$ (ESI) $m / z=431[\mathrm{M}]^{+}$. Anal. Calcd for $\overline{\mathrm{C}}_{22} \mathrm{H}_{26} \mathrm{ClN}_{3} \mathrm{O}_{4} \cdot 0.5 \mathrm{H}_{2} \mathrm{O}$ : C, 59.93; H, 6.17; N, 9.53. Found: C, 60.04; H, 6.36; N, 9.60.

(E)-N-((2S)-1-((4-(2-Aminocyclopropyl)phenyl)amino)1-oxo-3-phenylpropan-2-yl)-3-(4-hydroxy phenyl)acrylamide Hydrochloride (19i) The title compound was obtained from compounds $\mathbf{1 1}$ and $\mathbf{1 7} \mathbf{i}$ according to the synthetic procedure of $\mathbf{1 5 a}$ in yield $52 \%$. Analytical data for 19i: IR ( $\left.\mathrm{KBr}, \mathrm{cm}^{-1}\right)$ : 3435, 3218, 1732, 1618, 1576, 1252, 1171; ${ }^{1} \mathrm{H}-\mathrm{NMR}$ (DMSO- $d_{6}, 300 \mathrm{MHz}, \delta$ ppm) 10.11 (brs, $1 \mathrm{H}$, N $\underline{H C O}$ ), 8.30 (brs, 3H, $\underline{\mathrm{H}}_{3} \mathrm{Cl}$ ), 7.70 (d, 2H, $\left.J=6.9 \mathrm{~Hz}, \mathrm{ArH}\right)$, $7 . \overline{39}(\mathrm{~d}, 1 \mathrm{H}, J=16.2 \mathrm{~Hz}, \overline{\mathrm{ArCH}}=), 7.23-7.28$ (m, 3H, Ar-H), 7.12-7.19 (m, 7H, Ar-H), $6.59(\mathrm{~d}, 1 \mathrm{H}, J=16.2 \mathrm{~Hz}, \mathrm{CH}=\mathrm{CH}-$ Ar), 5.09 (m, 1H, NCHCO), $3.10\left(\mathrm{~d}, 2 \mathrm{H}, J=6.0 \mathrm{~Hz}, \overline{\mathrm{PhCH}_{2}}\right)$, $2.73(\mathrm{~m}, 1 \mathrm{H}, \mathrm{CHN}), 2.27(\mathrm{~m}, 1 \mathrm{H}, \mathrm{PhCH}), 1.34(\mathrm{~m}, 1 \mathrm{H}, \mathrm{CHH}$ cyclopropane), 1.15 (m, 1H, CHH cyclopropane); MS (ESI) $m / z=507[\mathrm{M}]^{+}$. Anal. Calcd for $\mathrm{C}_{28} \mathrm{H}_{30} \mathrm{ClN}_{3} \mathrm{O}_{4}: \mathrm{C}, 66.20 ; \mathrm{H}$, 5.95; N, 8.27. Found: C, 66.08; H, 6.04; N, 8.11.

(2S)-N-(4-(2-Aminocyclopropyl)phenyl)-2-((E)-3-(4-hydroxyphenyl)acrylamido)-3-methylbutanamide Hydrochloride (19j) The title compound was obtained from compounds $\mathbf{1 1}$ and $\mathbf{1 7} \mathbf{j}$ according to the synthetic procedure of $15 \mathrm{a}$ in yield $55 \%$. Analytical data for $19 \mathrm{j}$ : IR $\left(\mathrm{KBr}, \mathrm{cm}^{-1}\right)$ : $3459,3228,1716,1621,1568,1246,1178 ;{ }^{1} \mathrm{H}-\mathrm{NMR}$ (DMSO- $d_{6}$, $300 \mathrm{MHz}, \delta$ ppm) 10.28 (brs, 1H, PhNHCO), 8.33 (brs, 3H, $\left.\mathrm{NH}_{3} \mathrm{Cl}\right), 7.70(\mathrm{~d}, J=6.9 \mathrm{~Hz}, 2 \mathrm{H}, \mathrm{ArH}), 7.59$ (d, 2H, $J=6.9 \mathrm{~Hz}$, Ar-H), 7.39 (d, 1H, J=16.2 Hz, $\mathrm{ArCH}=), 7.12-7.18(\mathrm{~m}, 5 \mathrm{H}$, Ar-H), $6.56(\mathrm{~d}, 1 \mathrm{H}, J=16.2 \mathrm{~Hz}, \mathrm{CH}=\mathrm{CH}-\mathrm{Ar}), 4.67(\mathrm{~m}, 1 \mathrm{H}$, $\mathrm{NCHCO}), 2.81(\mathrm{~m}, 1 \mathrm{H}, \mathrm{CHN}), 2.6 \overline{9}(\mathrm{~m}, 1 \mathrm{H}, \mathrm{NCHCH}), 2.30$ (m, 1H, PhCH $), 1.36(\mathrm{~m}, 1 \overline{\mathrm{H}}, \mathrm{CH} \underline{\mathrm{H}}$ cyclopropane), $1.21 \mathrm{~m}, 1 \mathrm{H}$, C $\underline{H} \mathrm{H}$ cyclopropane), 0.95 (d, $\left.6 \mathrm{H}, \bar{J}=7.5 \mathrm{~Hz}, 2 \times \mathrm{CH}_{3}\right)$; MS (ESI) $m / z=459[\mathrm{M}]^{+}$. Anal. Calcd for $\mathrm{C}_{24} \mathrm{H}_{30} \mathrm{ClN}_{3} \mathrm{O}_{4}: \mathrm{C}, 62.67 ; \mathrm{H}$, 6.57; N, 9.14. Found: C, 62.53; H, 6.75; N, 9.04.

(2S)-N-(4-(2-A minocyclopropyl)phenyl)-2-((E)-3-(4hydroxyphenyl)acrylamido)-3-methylpentanamide Hydrochloride (19k) The title compound was obtained from compounds 11 and $\mathbf{1 7 k}$ according to the synthetic procedure of $15 \mathbf{a}$ in yield $50 \%$. Analytical data for 19k: IR $\left(\mathrm{KBr}, \mathrm{cm}^{-1}\right)$ : 3472, 3244, 2934, 1720, 1616, 1570, 1245, 1181; ${ }^{1} \mathrm{H}-\mathrm{NMR}$ (DMSO- $d_{6}, 300 \mathrm{MHz}, \delta$ ppm) 10.20 (brs, 1H, PhN $\underline{H C O}$ ), 8.28 (brs, 3H, $\underline{\mathrm{H}}_{3} \mathrm{Cl}$ ), 7.67 (d, $\left.2 \mathrm{H}, J=6.9 \mathrm{~Hz}, \mathrm{ArH}\right), 7.38$ (d, $1 \mathrm{H}$, $J=16.2 \mathrm{~Hz}, \overline{\mathrm{ArCH}}=), 7.10-7.19$ (m, 5H, Ar-H), $6.58(\mathrm{~m}, 1 \mathrm{H}$, $\mathrm{CH}=\mathrm{CH}-\mathrm{Ar}), 2.71(\mathrm{~m}, 1 \mathrm{H}, \mathrm{CHN}), 4.53$ (m, 1H, NCHCO), 2.26 $(\mathrm{m}, 1 \mathrm{H}, \mathrm{PhCH}), 2.15(\mathrm{~m}, 1 \overline{\mathrm{H}}, \mathrm{NCHCH}), 1.35(\mathrm{~m}, 1 \mathrm{H}, \mathrm{CH}$ cyclopropane), $1.13-1.18$ (m, 4H, $\mathrm{CH}$ cyclopropane, $\left.\mathrm{CH}_{3}\right)$, $0.91\left(\mathrm{~m}, 3 \mathrm{H}, \mathrm{CH}_{3}\right)$; MS (ESI) $m / z=473\left[\mathrm{M}^{+}\right.$. Anal. Calcd for $\mathrm{C}_{25} \mathrm{H}_{32} \mathrm{ClN}_{3} \mathrm{O}_{4} \cdot 2 \mathrm{H}_{2} \mathrm{O}: \mathrm{C}, 58.87 ; \mathrm{H}, 7.11 ; \mathrm{N}, 8.24$. Found: $\mathrm{C}$, 58.68; H, 7.23; N, 8.15.

(2S)-N-(4-(2-Aminocyclopropyl)phenyl)-1-((E)-3-(4hydroxy-3-methoxyphenyl)acryloyl)pyrrolidine-2-carboxamide Hydrochloride (191) The title compound was obtained from compounds $\mathbf{1 1}$ and $\mathbf{1 7 1}$ according to the synthetic procedure of $\mathbf{1 5 a}$ in yield $47 \%$. Analytical data for 19l: IR $\left(\mathrm{KBr}, \mathrm{cm}^{-1}\right)$ : 3465, 3246, 2911, 1716, 1625, 1560, 1252, 1172; ${ }^{1} \mathrm{H}-\mathrm{NMR}$ (DMSO- $\left.d_{6}, 300 \mathrm{MHz}, \delta \mathrm{ppm}\right) 10.24$ (brs, $1 \mathrm{H}, \mathrm{PhN} \underline{\mathrm{HCO}}$ ), 8.35 (brs, 3H, $\mathrm{NH}_{3} \mathrm{Cl}$ ), 7.76 (d, $2 \mathrm{H}$,
$J=6.9 \mathrm{~Hz}, \mathrm{ArH}), 7.41$ (d, 1H, $J=16.2 \mathrm{~Hz}, \mathrm{ArCH}=), 7.13-7.22$ (m, 5H, Ar-H), $6.63(\mathrm{~d}, 1 \mathrm{H}, J=16.2 \mathrm{~Hz}, \mathrm{CH}=\mathrm{CH}-\mathrm{Ar}), 4.45$ (m, 1H, NCHCO), $3.46\left(\mathrm{~m}, 2 \mathrm{H}, \mathrm{NCH}_{2}\right), 2.80$ (m, 1H, $\left.\mathrm{CHN}\right)$, $2.31(\mathrm{~m}, 1 \mathrm{H}, \mathrm{PhCH}), 2.04\left(\mathrm{~m}, 2 \mathrm{H}, \mathrm{NCHCH}_{2}\right), 1.68(\mathrm{~m}, 2 \mathrm{H}$, $\left.\mathrm{NCH}_{2} \mathrm{CH}_{2}\right), 1.38$ (m, 1H, CHㅡㅡ cyclopropane), $1.23(\mathrm{~m}, 1 \mathrm{H}$, $\mathrm{CHH}$ cyclopropane); MS (ESI) $m / z=457[\mathrm{M}]^{+}$. Anal. Calcd for $\mathrm{C}_{24} \mathrm{H}_{28} \mathrm{ClN}_{3} \mathrm{O}_{4}$ : C, 62.95; H, 6.16; N, 9.18. Found: C, 63.06; H, 6.24; N, 9.01.

Enzyme Assay LSD1 inhibition. The LSD1 screening biochemical assay kit was purchased from Cayman Chemical (700120). Test compounds were diluted to $20 \times$ the desired test concentration in $100 \%$ DMSO and $2.5 \mu \mathrm{L}$ of the diluted drug sample was added to a black 96-well plate (Corning, cat. 3693). The LSD1 enzyme stock was diluted with assay buffer, and $40 \mu \mathrm{L}$ of the diluted LSD1 enzyme was added to the appropriate wells. Substrate, consisting of horseradish peroxidase, H3K4me2 peptide corresponding to the first 21 amino acids of the N-terminal tail of histone H3, and 10-acetyl-3,7dihydroxyphenoxazine was then added to wells. Resorufin was analyzed on an Envision plate reader with an excitation wavelength of $530 \mathrm{~nm}$ and an emission wavelength of $595 \mathrm{~nm}$ in order to evaluate the inhibition rate of the tested compound. The $\mathrm{IC}_{50}$ values were calculated using GraphPad Prism version 4.0 (GraphPad Software, San Diego, CA, U.S.A.).

MAO-A and MAO-B inhibition. MAO-A and MAO-B were purchased from Sigma (catalogue number M 7316 and M 7441). The MAO Glo Assay kit (Promega, catalogue number V1402) was used to measure the effect of inhibitors on MAO-A and MAO-B activity. The assay was performed at room temperature in $50 \mu \mathrm{L}(25 \mu \mathrm{L}$ reaction solution $+25 \mu \mathrm{L}$ detection reagent) in 96 well half area white plates (Corning, cat. 3693) on a Tecan Freedom EVO liquid handler (Tecan Group Ltd.). $50 \mathrm{~nm}$ MAO-A or $125 \mathrm{~nm}$ MAO-B were incubated with different inhibitor concentrations for $15 \mathrm{~min}$ at RT in MAO-A or MAO-B Buffer (MAO Glo Assay kit). Reaction was started with the addition of $40 \mathrm{~mm}$ MAO substrate for MAO-A or $14 \mathrm{~mm}$ for MAO-B. The reaction was stopped after $30 \mathrm{~min}$ with the detection reagent. Luminescence was measured after 20 min incubation in the dark using a microplate reader. All compounds were tested twice in duplicate and $\mathrm{IC}_{50}$ values were calculated using GraphPad Prism version 4.0 (GraphPad Software).

Cell Culture HGC-27, HCT-116, LP-1, or human normal cell line CCD841 cells were maintained in 10\% fetal bovine serum (FBS) Dulbecco's modified Eagle's medium (DMEM) medium (Gibco, Invitrogen), which were supplemented with $10 \%$ fetal calf serum (PAA, Austria) and antibiotics [100 IU/ $\mathrm{mL}$ penicillin and $100 \mathrm{IU} / \mathrm{mL}$ streptomycin (Amresco)]. All of the cell lines were purchased from the Shanghai Institute of Cell Biology (Shanghai, China) and were grown at $37^{\circ} \mathrm{C}$ in a $5 \% \mathrm{CO}_{2}$ atmosphere with medium changes every $2 \mathrm{~d}$.

MTT Assay The inhibitory effects on cell proliferation of test compounds were investigated by the MTT method. HGC-27, HCT-116, LP-1, or CCD841 cells at a final density of $1.0 \times 10^{4}$ cells/well were placed in 96 -well cell plates overnight and treated with or without different concentrations of test compounds for various periods of time. During the last $4 \mathrm{~h}$ culture, the cells were exposed to MTT $(5 \mathrm{mg} / \mathrm{mL})$, and the resulting formazan crystals were dissolved in $150 \mu \mathrm{L}$ of DMSO and measured using a spectrophotometer (Tecan) at a test wavelength of $570 \mathrm{~nm}$. Experiments were conducted in 
triplicate. Inhibition rate $(\%)=\left[\left(A_{\text {control }}-A_{\text {treated }}\right) / A_{\text {control }}\right] \times 100 \%$. The $\mathrm{IC}_{50}$ values were calculated using GraphPad Prism version 4.0 (GraphPad Software).

Western Blot Assay The inhibitory activity of LSD1 was determined by Western blot assay with the total lysates by radio immunoprecipitation assay (RIPA) buffer (Sigma R0278) or histone purified with kit from Epigentek (OP-0006). After harvested and lyzed, the cell lysates (50 $\mu \mathrm{g} / \mathrm{lane})$ were separated by sodium dodecyl sulfate-polyacrylamide gel electrophoresis (SDS-PAGE) (12\% Bis-tris gel) and transferred onto nitrocellulose membranes. Concentration of whole cell lysates and histone extracts were determined using a Micro BCA Protein Assay Kit (Thermo Scientific 23235). We used $5 \%$ bovine serum albumin (BSA) to block the membrane in the case of $\mathrm{H} 3 \mathrm{~K} 4 \mathrm{me} 1 / \mathrm{me} 2 / \mathrm{me} 3$ antibody and $5 \%$ fat-free milk for histone $\mathrm{H} 3$ antibody. The target proteins were probed with anti-H3K4me1, anti-H3K4me2, anti-H3K4me3, and anti-H3 antibodies (Biovision, 6864-25, 6865-25, 6866-25, and 6806-50), respectively. The bound antibodies were detected by horseradish peroxidase (HRP)-conjugated second antibodies and visualized using the enhanced chemiluminescent reagent.

Conflict of Interest The authors declare no conflict of interest.

\section{References}

1) Tsai H. C., Baylin S. B., Cell Res., 21, 502-517 (2011).

2) Füllgrabe J., Kavanagh E., Joseph B., Oncogene, 30, 3391-3403 (2011).

3) Shi Y., Lan F., Matson C., Mulligan P., Whetstine J. R., Cole P. A., Casero R. A., Shi Y., Cell, 119, 941-953 (2004).

4) Metzger E., Wissmann M., Yin N., Müller J. M., Schneider R., Peters A. H. F. M., Günther T., Buettner R., Schüle R., Nature (London), 437, 436-439 (2005).

5) Culhane J. C., Cole P. A., Curr. Opin. Chem. Biol., 11, 561-568 (2007).

6) Huang J., Sengupta R., Espejo A. B., Lee M. G., Dorsey J. A., Richter M., Opravil S., Shiekhattar R., Bedford M. T., Jenuwein T., Berger S. L., Nature (London), 449, 105-108 (2007).

7) Kontaki H., Talianidis I., Mol. Cell, 39, 152-160 (2010).

8) Schulte J. H., Lim S., Schramm A., Friedrichs N., Koster J., Versteeg R., Ora I., Pajtler K., Klein-Hitpass L., Kuhfittig-Kulle S.,
Metzger E., Schule R., Eggert A., Buettner R., Kirfel J., Cancer Res., 69, 2065-2071 (2009).

9) Zhao Z. K., Dong P., Gu J., Chen L., Zhuang M., Lu W. J., Wang D. R., Liu Y. B., Tumour Biol., 34, 173-180 (2013).

10) Wissmann M., Yin N., Müller J. M., Greschik H., Fodor B. D., Jenuwein T., Vogler C., Schneider R., Günther T., Buettner R., Metzger E., Schüle R., Nat. Cell Biol., 9, 347-353 (2007).

11) Lim S., Janzer A., Becker A., Zimmer A., Schüle R., Buettner R., Kirfel J., Carcinogenesis, 31, 512-520 (2010).

12) Hayami S., Kelly J. D., Cho H., Yoshimatsu M., Unoki M., Tsunoda T., Field H. I., Neal D. E., Yamaue H., Ponder B. A. J., Nakamura Y., Hamamoto R., Int. J. Cancer, 128, 574-586 (2011).

13) Liu K., Liu Y., Lau J. L., Min J., Pharmacol. Ther., 151, 121-140 (2015).

14) Ma L. Y., Zheng Y., Wang S., Wang B., Wang Z., Pang L., Zhang M., Wang J., Ding L., Li J., Wang C., Hu B., Liu Y., Zhang X., Wang J., Wang Z., Zhao W., Liu H., J. Med. Chem., 58, 1705-1716 (2015).

15) Mimasu S., Umezawa N., Sato S., Higuchi T., Umehara T., Yokoyama S., Biochemistry, 49, 6494-6503 (2010).

16) Binda C., Valente S., Romanenghi M., Pilotto S., Cirilli R., Karytinos A., Ciossani G., Botrugno O. A., Forneris F., Tardugno M., Edmondson D. E., Minucci S., Mattevi A., Mai A., J. Am. Chem. Soc., 132, 6827-6833 (2010).

17) Ueda R., Suzuki T., Mino K., Tsumoto H., Nakagawa H., Hasegawa M., Sasaki R., Mizukami T., Miyata N., J. Am. Chem. Soc., 131, 17536-17537 (2009).

18) Sharma S. K., Wu Y., Steinbergs N., Crowley M. L., Hanson A. S., Casero R. A. Jr., Woster P. M., J. Med. Chem., 53, 5197-5212 (2010).

19) Culhane J. C., Wang D., Yen P. M., Cole P. A., J. Am. Chem. Soc., 132, 3164-3176 (2010).

20) Wang J., Lu F., Ren Q., Sun H., Xu Z., Lan R., Liu Y., Ward D., Quan J., Ye T., Zhang H., Cancer Res., 71, 7238-7249 (2011).

21) Liang Y., Vogel J. L., Narayanan A., Peng H., Kristie T. M., Nat. Med., 15, 1312-1317 (2009).

22) Yang M., Culhane J. C., Szewczuk L. M., Jalili P., Ball H. L., Machius M., Cole P. A., Yu H., Biochemistry, 46, 8058-8065 (2007).

23) Ling Y., Wang Z., Wang X., Zhao Y., Zhang W., Wang X., Chen L., Huang Z., Zhang Y., Org. Biomol. Chem., 12, 4517-4530 (2014).

24) Lin Y., Xia X., Yao R., Ni L., Hu J., Guo W., Zhu B., Chem. Pharm. Bull., 62, 343-349 (2014).

25) Huang W. Y., Cai Y., Zhang Y., Nutr. Cancer, 62, 1-20 (2010). 